Zeszyty Naukowe Szkoły Głównej Gospodarstwa Wiejskiego w Warszawie Problemy Rolnictwa Światowego tom 17 (XXXII), zeszyt 3, 2017: 187-194

DOI: 10.22630/PRS.2017.17.3.65

Dorota Komorowska ${ }^{1}$

Szkoła Główna Gospodarstwa Wiejskiego w Warszawie

\title{
Efektywność gospodarowania zasobami w gospodarstwach sadowniczych
}

\section{Effectiveness of Production Resource Management in Orchard Farms}

\begin{abstract}
Synopsis. Celem opracowania jest ocena wyników gospodarowania zasobami produkcyjnymi w gospodarstwach sadowniczych na tle ogółu gospodarstw rolnych. Efektywność produkcyjna zasobów ziemi gospodarstw sadowniczych ukształtowała się na prawie dwukrotnie wyższym poziomie niż gospodarstw ogółem, produktywność zaangażowanego kapitału była zbliżona w obu grupach gospodarstw, zaś produktywność wydatkowanej pracy była mniejsza w gospodarstwach sadowniczych, ponieważ gospodarstwa te angażowały znacznie większe nakłady pracy. Gospodarstwa specjalizujące się w produkcji sadowniczej uzyskały znacznie wyższe dochody niż ogół gospodarstw rolnych, dlatego efektywność ekonomiczna gospodarowania zasobami była także większa w tych gospodarstwach, zwłaszcza dochodowość zasobów ziemi (ponad dwu i półkrotnie). Dopłaty do działalności gospodarstw rolnych miały znacznie mniejszy udział w dochodach gospodarstw sadowniczych niż w dochodach ogółu gospodarstw rolnych.
\end{abstract}

Slowa kluczowe: uprawy sadownicze, produkcja owoców, wyniki produkcji rolniczej, efektywność gospodarstw rolnych

\begin{abstract}
The aim of the study is to evaluate the results of management of production resources in orchard farms against the background of all farms. Production efficiency of the land resources of fruit farms was almost twice as high as that of the all farms, the productivity of the involved capital was similar in both groups of farms, and the productivity of the labour spent was smaller in the orchard farms, as these farms engaged significantly more labour. Farms specializing in orchard production achieved considerably higher incomes than all farms, so the economic efficiency of resource management was also higher in these holdings, especially the yield of land (more than two and a half times). It is worth emphasizing that the subsidies to farm businesses had a much lower share of the income of fruit farms than in the total income of agricultural holdings.
\end{abstract}

Key words: orchard crops, fruit production, results of agricultural production, effectiveness of farms

\section{Wstęp}

Produkcja owoców jest istotnym kierunkiem produkcji rolniczej w Polsce. Udział towarowej produkcji owoców w wartości towarowej produkcji roślinnej stanowi kilkanaście procent, w 2015 roku wyniósł ponad 15\%. W tymże roku odnotowano zmniejszenie wartości produkcji poszczególnych produktów rolnych, oprócz warzyw i owoców (Rolnictwo..., 2016). W strukturze powierzchni uprawy owoców, tj. drzew owocowych (sady) i krzewów owocowych dominują sady, a w ich obrębie sady jabłoniowe. W 2016 roku udział powierzchni sadów w ogólnej powierzchni uprawy owoców, a także udział powierzchni

${ }^{1}$ dr hab. inż., Katedra Ekonomiki Rolnictwa i Międzynarodowych Stosunków Gospodarczych

SGGW w Warszawie, ul. Nowoursynowska 166, 02-787 Warszawa, e-mail: dorota komorowska@sggw.pl 
sadów jabłoniowych w powierzchni sadów wyniósł $73 \%$. W strukturze produkcji owoców, dominuje również produkcja jabłek, która w 2016 roku stanowiła 78\% całkowitej produkcji owoców (Rynek owoców..., 2017).

Polska jest znaczącym producentem owoców w Europie, jak również na świecie. Wśród krajów Unii Europejskiej jesteśmy największym producentem jabłek, także wiśni, malin, porzeczek, aronii i borówki oraz znaczącym producentem truskawek i agrestu. Ważnym czynnikiem stymulującym rozwój krajowej produkcji owoców jest ich eksport, w tym przede wszystkim jabłek (Nosecka i in., 2012). Na eksport kierujemy znaczącą część produkcji świeżych owoców oraz przetworów z owoców. W 2016 roku eksport świeżych owoców wyniósł ponad $27 \%$ produkcji świeżych owoców, natomiast eksport przetworów owocowych stanowił 33\% produkcji przetworów z owoców (Rynek owoców..., 2017).

Głównym rynkiem zbytu dla polskich jabłek, a także truskawek, śliwek, wiśni i czereśni przez lata była Rosja, zaś po wprowadzeniu sankcji udawało się omijać ograniczenia i sprzedawać produkty ogrodnicze, w tym zwłaszcza jabłka, na rynku rosyjskim poprzez podmioty gospodarcze z innych krajów. W 2015 roku w Rosji zaostrzono kontrole, co spowodowało, że polskie owoce i warzywa w postaci nieprzetworzonej, zaczęły trafiać na rynek rosyjski praktycznie tylko w śladowych ilościach. Natomiast potencjał wzrostu popytu na jabłka w krajach azjatyckich i afrykańskich, gdzie następuje jego stały wzrost jest tak duży, że pomimo stałego wzrostu światowej produkcji i spadku spożycia w krajach o wysokich dochodach, całość produkcji jabłek jest zagospodarowywana (Brzozowski i in., 2015). Stwarza to perspektywę dla polskich producentów i eksporterów.

Obserwowane zmiany, jakie zachodzą w krajowej produkcji sadowniczej przejawiają się $\mathrm{w}$ poprawie organizacji i koncentracji produkcji, specjalizacji gospodarstw i wprowadzaniu do uprawy nowych i bardziej wydajnych odmian, a także w usprawnianiu dystrybucji, do czego przyczyniły się uwarunkowania organizacyjno-prawne rynku owoców i warzyw (regulacje prawne, wsparcie finansowe wspólnej organizacji rynku, zmiany w zakresie i formach pomocy dla grup producentów) (Filipiak, 2014). Z danych spisowych GUS-u wynika, że w 2010 roku w porównaniu do 2002 r. odnotowano znaczny wzrost powierzchni uprawy owoców - o $38,1 \%$, natomiast liczba gospodarstw prowadzących uprawy drzew i krzewów owocowych zmniejszyła się o 10,2\%. W efekcie średnia powierzchnia uprawy owoców $w$ gospodarstwach prowadzących uprawy owoców zwiększyła się z 0,86 do 1,31 ha, tj. o $52 \%$. W tym średnia powierzchnia uprawy drzew owocowych w sadach zwiększyła się z 0,79 do 1,35 ha, czyli o $71 \%$ (Uprawy ogrodnicze..., 2012).

Procesy specjalizacji i koncentracji produkcji powodują, że coraz więcej gospodarstw specjalizujących się $\mathrm{w}$ produkcji sadowniczej zwiększa swoją efektywność oraz konkurencyjność na rynku wewnętrznym, jak i zewnętrznym (Jabłońska i in., 2017b; Nosecka i in., 2012; Ziętara, Sobierajewska, 2012). Należy podkreślić, że mechanizm konkurencji działa ze szczególną siłą w sadownictwie, a także warzywnictwie, gdyż produkcja ogrodnicza jest intensywną, jednocześnie bardzo kapitałochłonną, szczególnie w krajach o mniej korzystnych warunkach klimatycznych, a do takich należy Polska (Jabłońska i in., 2017a). Ponadto dla Polski problem zewnętrznej konkurencji produkcji ogrodniczej nabiera szczególnego znaczenia, gdyż ma ona charakter wyraźnie proeksportowy (Józwiak i in., 2014), co zachęca to do analiz konkurencyjności gospodarstw ogrodniczych, jak również do oceny efektywności gospodarowania w tego typu gospodarstwach. 


\section{Cel i metodyka badań}

Celem opracowania jest ocena efektywności gospodarowania zasobami produkcyjnymi w gospodarstwach sadowniczych na tle ogółu gospodarstw rolnych objętych rachunkowością rolną w systemie FADN ${ }^{2}$ w 2015 roku. W badanym roku w próbie Polskiego FADN było: 12313 gospodarstw rolnych, w tym 354 gospodarstwa sadownicze. Zgodnie z założeniami obowiązującego systemu rachunkowości rolnej, badaniem są obejmowane tylko gospodarstwa przekraczające minimalny próg wielkości ekonomicznej (tzw. gospodarstwa towarowe) (Goraj, Mańko, 2009).

Według metodyki FADN, wyniki produkcyjne gospodarstw rolnych stanowi kategoria „produkcja ogółem”, czyli produkcja całkowita, która obejmuje produkcję rolniczą roślinną i zwierzęcą oraz pozostałą produkcję, a także przychody z dzierżawienia ziemi, wynajmu budynków, maszyn, świadczenia usług. Natomiast kategoria dochodowa według tejże metodyki to „dochód z rodzinnego gospodarstwa rolnego”, określana w niniejszym opracowaniu w skrócie jako „dochód z gospodarstwa rolnego”. Odpowiada dochodowi rolniczemu netto $\mathrm{z}$ uwzględnieniem dopłat do działalności gospodarstw rolnych. W celu określenia znaczenia dopłat $\mathrm{w}$ kształtowaniu poziomu dochodów badanych gospodarstw obliczono „dochód z gospodarstwa rolnego bez dopłat” oraz „dochód z gospodarstwa rolnego z dopłatami”.

Efektywność gospodarowania zasobami produkcyjnymi w gospodarstwach rolnych mierzy się odnosząc ujęcie wartościowe efektów produkcyjnych oraz wyniki ekonomiczne gospodarstw do wkładu czynników wytwórczych zaangażowanych w ich uzyskanie. Odniesienie odpowiednio wyników produkcyjnych pozwala ocenić efektywność produkcyjną, a wyników ekonomicznych - efektywność ekonomiczną. Odniesienie wartości uzyskanej produkcji do wielkości zasobów ziemi użytkowanych $\mathrm{w}$ badanych gospodarstwach pozwoliło ustalić produktywność zasobów ziemi. Odniesienie wartości produkcji do wielkości wkładu pracy w jej wytworzenie (wkładu pracy przeliczonego na pełny wymiar czasu pracy) pozwoliło obliczyć produktywność wydatkowanej pracy (ekonomiczną wydajność pracy). Natomiast przeliczenie wartości produkcji na $100 \mathrm{zł}$ zaangażowanego kapitału w procesy wytwarzania porównywanych gospodarstw pozwoliło ustalić produktywność kapitału przypadającą na jego jednostkę. Z kolei odniesienie odpowiednio wyniku ekonomicznego (dochodu z gospodarstwa rolnego $\mathrm{z}$ dopłatami) do wkładu zasobów produkcyjnych zaangażowanych w jego uzyskanie pozwoliło ocenić efektywność ekonomiczną gospodarowania zasobami w badanych gospodarstwach (dochodowość zasobów ziemi, wydatkowanej pracy i zaangażowanego kapitału).

\section{Potencjał produkcyjny analizowanych gospodarstw}

Przeciętna powierzchnia użytków rolnych (UR) porównywanych grup gospodarstw w 2015 roku różniła się znacząco. Gospodarstwa nastawione na produkcję sadowniczą były ponad dwukrotnie mniejsze obszarowo od ogółu gospodarstw rolnych, ich średnia powierzchnia UR wyniosła 9,5 ha, natomiast gospodarstw ogółem - 19,4 ha. Uprawy

\footnotetext{
${ }^{2}$ FADN to jednolity system zbierania danych rachunkowych we wszystkich krajach członkowskich UE, służący m.in. do kreowania wspólnej polityki rolnej. W Polsce od 2004 roku IERiGŻ-PIB prowadzi badania rachunkowości rolnej w systemie FADN, określanym jako Polski FADN.
} 
sadownicze w gospodarstwach sadowniczych zajmowały powierzchnię 7,2 ha (w gospodarstwach ogółem 0,5 ha). Zarówno gospodarstwa sadownicze, jak i gospodarstwa ogółem gospodarowały zasobami ziemi, które były częściowo dzierżawione (tab. 1). Na podkreślenie zasługuje fakt, że pod względem wielkości obszarowej, przeciętne polskie gospodarstwo sadownicze różni się nieznacznie od unijnego, ponieważ średnia powierzchnia UR gospodarstwa sadowniczego w krajach UE w 2014 roku wyniosła 10,6 ha, w tym powierzchnia upraw sadowniczych 8,0 ha (średnia powierzchnia dla ogółu unijnych gospodarstw w tymże roku wynosiła około 32 ha) (Farm economy..., 2017).

W oparciu o dane rachunkowości rolnej FADN z zakresu zasobów pracy gospodarstw rolnych można podać tylko wkład zasobów pracy w procesy produkcyjne gospodarstw, czyli nakłady pracy. $Z$ danych rachunkowych wynika, że roczne nakłady pracy ogółem $\mathrm{w}$ przeliczeniu na pełnozatrudnionego $\mathrm{w}$ ciągu roku ( $\mathrm{w} \mathrm{AWU}^{3}$ ) były większe $\mathrm{w}$ gospodarstwach sadowniczych, co wynikało z bardziej pracochłonnej produkcji w tego typu gospodarstwach. W związku z tym gospodarstwa sadownicze angażowały większe zasoby pracy najemnej niż ogół gospodarstw rolnych.

Tabela 1. Zasoby produkcyjne porównywanych gospodarstw

Table 1. Production resources of comparable farms

\begin{tabular}{l|cc}
\hline \multicolumn{1}{c|}{ Wyszczególnienie } & \multicolumn{2}{c}{ Gospodarstwa } \\
\hline Średnia powierzchnia użytków rolnych [ha] & ogółem & 9,5 \\
- w tym dzierżawionych [ha] & 19,4 & 0,7 \\
Nakłady pracy ogółem [AWU] & 5,1 & 2,13 \\
- w tym pracy najemnej [AWU] & 1,69 & 0,76 \\
Aktywa ogółem [zł] & 0,22 & 668100 \\
Aktywa ogółem [zł/ha] & 722420 & 70326 \\
\hline
\end{tabular}

Źródło: obliczenia własne na podstawie (Wyniki standardowe..., 2015).

Potencjał zasobów kapitałowych gospodarstw rolnych stanowią środki produkcyjne trwałe i obrotowe, których wartość obrazują aktywa ogółem. Zasoby kapitałowe porównywanych grup gospodarstw stanowiły w głównej mierze środki trwałe, w tym budynki, maszyny i urządzenia w wyposażeniu budynków oraz uprawy trwałe, zwłaszcza w przypadku gospodarstw sadowniczych. Ich wartość w przeliczeniu na 1 ha UR była większa w gospodarstwach sadowniczych prawie o $50 \%$, ponieważ produkcja sadownicza jest bardzo kapitałochłonną (tab. 1).

\section{Wyniki produkcyjne i produktywność czynników wytwórczych}

Wartość produkcji ogółem w badanych gospodarstwach specjalizujących się w produkcji sadowniczej kształtowała przede wszystkim produkcja owoców, która stanowiła ponad $90 \%$ wartości produkcji całkowitej (tab. 2). Niewielki udział w gospodarstwach sadowniczych miała produkcja zwierzęca (niespełna 0,3\%). Natomiast w gospodarstwach

\footnotetext{
${ }^{3}$ AWU - jednostka przeliczeniowa nakładów pracy według metodyki FADN: 1 jednostka AWU $=2120$ godzin pracy ogółem/rok. W nakładach pracy ogółem ujmuje się nakłady pracy własnej rolnika i jego rodziny (FWU) oraz nakłady pracy najemnej (AWU).
} 
ogółem wyniki produkcyjne kształtowała $\mathrm{w}$ połowie produkcja roślinna, a w połowie produkcja zwierzęca. W gospodarstwach tych dominowała produkcja zbóż, która stanowiła $23 \%$ wartości produkcji całkowitej, znaczący udział miała produkcja mleka (15\%), żywca wieprzowego (11\%), wołowego $(8 \%)$ oraz warzyw $(10 \%)$.

Tabela 2. Wartość i struktura produkcji porównywanych gospodarstw

Table 2. Production value and structure of compared farms

\begin{tabular}{l|cccc}
\hline \multirow{2}{*}{ Wyszczególnienie } & \multicolumn{3}{c}{ Gospodarstwa } \\
& \multicolumn{2}{|c}{ ogółem } & \multicolumn{2}{c}{ sadownicze } \\
& $\begin{array}{c}\text { wartość } \\
\text { produkcji [zł] }\end{array}$ & $\begin{array}{c}\text { struktura } \\
\text { produkcji [\%] }\end{array}$ & $\begin{array}{c}\text { wartość } \\
\text { produkcji [zł] }\end{array}$ & $\begin{array}{c}\text { struktura } \\
\text { produkcji [\%] }\end{array}$ \\
\hline Produkcja ogółem & 122407 & 100,0 & 111238 & 100,0 \\
Produkcja roślinna, w tym: & 63736 & 52,1 & 109615 & 98,5 \\
- zboża & 28094 & 23,0 & 1696 & 1,5 \\
- ziemniaki & 3587 & 2,9 & 226 & 0,2 \\
- warzywa & 12653 & 10,3 & 2723 & 2,4 \\
- owoce & 6514 & 5,3 & 101401 & 91,2 \\
Produkcja zwierzęca, w tym: & 57250 & 46,8 & 315 & 0,3 \\
- mleko & 18578 & 15,2 & 28 & 0,02 \\
- żywiec wołowy & 10087 & 8,2 & 111 & 0,1 \\
- żywiec wieprzowy & 13528 & 11,1 & 25 & 0,02 \\
\hline
\end{tabular}

Źródło: jak w tab. 1.

Odniesienie wyników produkcyjnych porównywanych gospodarstw do wkładu czynników wytwórczych zaangażowanych w ich uzyskanie pozwoliło obliczyć produktywność zasobów analizowanych grup gospodarstw (tab. 3). W związku z tym, że gospodarstwa sadownicze były ponad dwukrotnie mniejsze obszarowo od gospodarstw ogółem a ich wyniki produkcyjne ukształtowały się na poziomie niższym tylko o $9 \%$ to efektywność produkcyjna ich zasobów ziemi była prawie dwukrotnie większa niż ogółu gospodarstw. Produktywność wydatkowanej pracy była mniejsza w gospodarstwach sadowniczych co wynikało $\mathrm{z}$ bardziej pracochłonnej produkcji w tych gospodarstwach, natomiast produktywność zaangażowanego kapitału była zbliżona $\mathrm{w}$ obu grupach porównywanych gospodarstw.

Tabela 3. Produktywność zasobów analizowanych gospodarstw

Table 3. Resource productivity in analyzed farms

\begin{tabular}{l|cc}
\multicolumn{1}{c|}{ Wyszczególnienie } & \multicolumn{2}{c}{ Gospodarstwa } \\
& ogółem & sadownicze \\
\hline Produktywność ziemi [zł/ha] & 6310 & 11709 \\
Ekonomiczna wydajność pracy [zł/AWU] & 72430 & 52224 \\
Produktywność na 100 zł aktywów ogółem [zł] & 16,9 & 16,2 \\
\hline
\end{tabular}

Źródło: jak w tab. 1. 


\section{Wyniki ekonomiczne i dochodowość czynników wytwórczych}

Dochód z gospodarstwa rolnego stanowi opłatę zaangażowania czynników wytwórczych gospodarstw rolnych w ich procesy produkcyjne. Syntetyczny rachunek wyników ekonomicznych porównywanych grup gospodarstw przedstawiono w tabeli 4 .

Koszty materiałowe działalności produkcyjnej gospodarstw sadowniczych były ponad dwukrotnie niższe niż ogółu gospodarstw rolnych i wynikały przede wszystkim z kosztów zużytych nawozów mineralnych i środków ochrony roślin (herbicydów, fungicydów, zoocydów) oraz kosztów energii elektrycznej. Koszty materiałowe ogółu gospodarstw rolnych ukształtowały w połowie koszty związane z produkcją roślinną, a w połowie związane z produkcją zwierzęcą, w tym głównie koszty nawożenia i ochrony roślin oraz żywienia utrzymywanych zwierząt. Koszty materiałowe w gospodarstwach sadowniczych stanowily 45\% kosztów całkowitych tychże gospodarstw (w gospodarstwach ogółem ponad 70\%).

Ponad dwukrotnie niższy poziom kosztów materiałowych w gospodarstwach sadowniczych wiązał się z tym, że były one także ponad dwukrotnie mniejsze obszarowo od ogółu gospodarstw rolnych. Natomiast gospodarstwa sadownicze prowadzą intensywną działalność produkcyjną (Jabłońska i in., 2017a), co potwierdzają wyniki niniejszej analizy porównawczej $^{4}$ (tab. 4).

Koszty amortyzacji środków trwałych były wyższe w gospodarstwach specjalizujących się w produkcji sadowniczej, co powodowały koszty amortyzacji sadów (nasadzenia w sadach, prowadzenie sadów $\mathrm{w}$ okresie inwestycyjnym). Ponadto wyższe $\mathrm{w}$ tych gospodarstwach były także koszty zewnętrznych czynników produkcji, głównie w związku Z wyższymi kosztami wynagrodzeń, ponieważ gospodarstwa sadownicze angażowały większe zasoby pracy najemnej. Natomiast podatki i inne opłaty od ziemi oraz budynków były wyższe w gospodarstwach ogółem.

Tabela 4. Rachunek wyników porównywanych gospodarstw

Table 4. Income statement in comparable farms

\begin{tabular}{l|cccc}
\hline \multicolumn{1}{c|}{ Wyszczególnienie } & \multicolumn{4}{c}{ Gospodarstwa } \\
& \multicolumn{2}{c}{ ogółem } & \multicolumn{2}{c}{ sadownicze } \\
& {$[\mathrm{zl}]$} & {$[\mathrm{zl} / \mathrm{ha}]$} & {$[\mathrm{zl}]$} & {$[\mathrm{zl} / \mathrm{ha}]$} \\
\hline Produkcja ogółem & 122407 & 6310 & 111238 & 11709 \\
Koszty materiałowe & 81830 & 4218 & 38790 & 4083 \\
Koszty amortyzacji & 20591 & 1061 & 30759 & 3238 \\
Koszty zewnętrznych czynników produkcji & 9751 & 503 & 16253 & 1711 \\
Podatki, opłaty & 1674 & 86 & 1063 & 112 \\
Saldo podatku VAT & -1007 & -52 & 150 & 16 \\
Koszty ogółem & 114853 & 5920 & 86715 & 9128 \\
Dochód z gospodarstwa rolnego bez dopłat & 7554 & 389 & 24673 & 2597 \\
Dopłaty & 25533 & 1316 & 15072 & 1587 \\
Dochód z gospodarstwa rolnego z dopłatami & 33087 & 1706 & 39745 & 4184 \\
\hline
\end{tabular}

Źródło: jak w tab. 1.

\footnotetext{
${ }^{4}$ Poziom intensywności produkcji obrazuje przede wszystkim poziom kosztów ogółem, ale także kosztów
} materiałowych na 1 ha UR. 
W końcowym rezultacie, koszty produkcji ogółem w gospodarstwach sadowniczych były niższe prawie o $25 \%$, dlatego ich wyniki ekonomiczne ukształtowały się na znacznie wyższym poziomie niż gospodarstw ogółem (ponad trzykrotnie wyższym). Dochód przeciętnego gospodarstwa sadowniczego (bez dopłat) wyniósł 24673 zl, natomiast przeciętny dochód ogółu gospodarstw rolnych -7554 zł (w przeliczeniu na 1 ha UR odpowiednio 2597 zł i 389 zł).

W przypadku gospodarstw ogółem o poziomie wyników końcowych zadecydował w głównym stopniu poziom dopłat do działalności produkcyjnej oraz inwestycyjnej uzyskiwany przez gospodarstwa rolne. Według metodyki FADN dopłaty do działalności gospodarstw rolnych są uwzględniane przy obliczaniu dochodu z gospodarstwa rolnego.

Tabela 5. Dochodowość zasobów porównywanych gospodarstw

Table 5 . The profitability of resources in the comparable farms

\begin{tabular}{l|cc}
\multicolumn{1}{c|}{ Wyszczególnienie } & \multicolumn{2}{c}{ Gospodarstwa } \\
& ogółem & sadownicze \\
\hline Dochód z gospodarstwa rolnego na 1 ha UR [zł/ha] & 1706 & 4184 \\
Dochodowość pracy własnej [zł/osobę] & 22508 & 28801 \\
Dochodowość aktywów ogółem [\%] & 4,6 & 5,8 \\
\hline
\end{tabular}

Źródło: jak w tab. 1

Udział dopłat w dochodach gospodarstw rolnych ogółem wyniósł aż 77\%, natomiast gospodarstw sadowniczych $-38 \%$, co wskazuje na dominującą rolę dopłat w kształtowaniu poziomu dochodów ogółu gospodarstw rolnych. Dopłaty do działalności gospodarstw rolnych mają znaczący udział w dochodach zarówno gospodarstw rolnych w Polsce, jak i pozostałych krajów Unii Europejskiej. W krajach UE-15, od 1995 roku udział dopłat w dochodach gospodarstw rolnych ogółem był przeważający i wzrastał, a w 2009 roku przekraczał nawet $100 \%$ (Runowski, 2014). W Polsce bardzo wysoki poziom wsparcia dochodów jest obserwowany zwłaszcza w przypadku gospodarstw wielokierunkowych oraz nastawionych na uprawy polowe (Goraj, Mańko, 2013), natomiast w przypadku gospodarstw warzywniczych dopłaty nie mają dużego wpływu na poziom dochodów uzyskiwanych przez te gospodarstwa (Ziętara, Sobierajewska, 2013).

Efektywność ekonomiczną gospodarowania zasobami w badanych gospodarstwach sadowniczych na tle ogółu gospodarstw rolnych, czyli dochodowość zasobów ziemi, wydatkowanej pracy i zaangażowanego kapitału przedstawiono w tabeli 5 . W związku z tym, że poziom uzyskanych dochodów był wyraźnie wyższy w przypadku gospodarstw sadowniczych to wskaźniki dochodowości zasobów były także wyższe w tych gospodarstwach, zwłaszcza dochodowości zasobów ziemi (prawie dwu i półkrotnie).

\section{Podsumowanie}

Badane gospodarstwa nastawione na produkcję owoców w porównaniu do ogółu gospodarstw rolnych użytkowały ponad dwukrotnie mniejszą powierzchnię zasobów ziemi, ale ich działalność produkcyjna była bardziej intensywna, dlatego uzyskały wyniki produkcyjne niższe niespełna o $10 \%$. W efekcie, produktywność zasobów ziemi gospodarstw sadowniczych ukształtowała się na prawie dwukrotnie wyższym poziomie niż gospodarstw 


\section{D. Komorowska}

ogółem, produktywność zaangażowanego kapitału była zbliżona w obu grupach gospodarstw, zaś produktywność wydatkowanej pracy była mniejsza w gospodarstwach sadowniczych, ponieważ gospodarstwa te angażowały znacznie większe nakłady pracy.

Gospodarstwa specjalizujące się w produkcji sadowniczej uzyskały znacznie lepsze wyniki ekonomiczne niż ogół gospodarstw rolnych, dlatego dochodowość ich zasobów produkcyjnych była także większa, zwłaszcza dochodowość zasobów ziemi (ponad dwu i półkrotnie). Zatem gospodarstwa sadownicze były bardziej efektywne ekonomicznie. $\mathrm{Na}$ podkreślenie zasługuje fakt, że dopłaty do działalności gospodarstw rolnych miały znacznie mniejszy udział w dochodach gospodarstw sadowniczych niż w dochodach ogółu gospodarstw rolnych.

\section{Literatura}

Brzozowski, P., Marosz, A., Zmarlicki, K. (2015). Uwarunkowania w produkcji ogrodniczej w Polsce w 2015 roku, Instytut Ogrodnictwa, Skierniewice.

Farm economy focus by sector. Farms specialised in orchards (fruits) in the EU, European Commission, 2017. Pobrano z: https://ec.europa.eu/agriculture/sites/agriculture/files/fadn/documents/orchards_en.pdf.

Filipiak, T. (2014). Zmiany na rynku warzyw i w gospodarstwach warzywniczych w Polsce po integracji z Unią Europejską, SGGW, Warszawa.

Goraj, L., Mańko, S. (2013). Analiza sytuacji ekonomicznej towarowych gospodarstw rolnych w latach 2004-2010, Powszechny Spis Rolny 2010, GUS, Warszawa.

Goraj, L., Mańko, S. (2009). Rachunkowość i analiza ekonomiczna w indywidualnym gospodarstwie rolnym, Centrum doradztwa i Informacji Difin, Warszawa.

Jabłońska, L., Filipiak, T., Gunerka, L. (2017a). Konkurencyjność kosztowa gospodarstw ogrodniczych w Polsce i wybranych krajach UE. Zeszyty Naukowe Szkoły Gtównej Gospodarstwa Wiejskiego w Warszawie Problemy Rolnictwa Światowego, 17(1), 63-72.

Jabłońska, L., Gunerka, L., Filipiak, T. (2017b). Efektywność ekonomiczna gospodarstw ogrodniczych w wybranych krajach Unii Europejskiej. Roczniki Naukowe Stowarzyszenia Ekonomistów Rolnictwa i Agrobiznesu, 19(2), 77-82.

Józwiak, W., Kagan, A., Niewęgłowska, G., Skarżyńska, A., Sobierajewska, J., Zieliński, M., Ziętara, W. (2014) Efektywność, koszty produkcji i konkurencyjność gospodarstw rolnych obecnie i w perspektywie średniooraz długookresowej. IERiŻ-PIB, Warszawa.

Nosecka, B., Bugała, A., Paszko, D., Zaremba, Ł. (2012). Sytuacja na światowym rynku wybranych produktów ogrodniczych i jej wpływ na polski rynek ogrodniczy, Konkurencyjność polskiej gospodarki żywnościowej $w$ warunkach globalizacji i integracji europejskiej, nr 39, IERiŻ-PIB, Warszawa.

Rolnictwo w 2015 r., GUS, Warszawa, 2016.

Rynek owoców i warzyw, stan i perspektywy, IERiŻ-PIB, nr 50, Warszawa, lipiec 2017.

Runowski, H. (2014). Ekonomika rolnictwa - przemiany w gospodarstwach rolnych. W: N. Drejerska (red.), Rolnictwo, gospodarka żywnościowa, obszary wiejskie - 10 lat w Unii Europejskiej, SGGW, Warszawa, 3148.

Uprawy ogrodnicze, Powszechny Spis Rolny 2010, GUS, Warszawa 2012.

Wyniki standardowe 2015 uzyskane przez gospodarstwa rolne uczestniczace w Polskim FADN, Warszawa, 2016. Pobrano z: www.fadn.pl.

Ziętara, W., Sobierajewska, J. (2012). Gospodarstwa ogrodnicze w Polsce i w wybranych krajach Unii Europejskiej, Konkurencyjność polskiej gospodarki żywnościowej w warunkach globalizacji i integracji europejskiej, $\mathrm{nr} 58$, IERiŻ-PIB, Warszawa.

Ziętara, W., Sobierajewska, J. (2013). Polskie gospodarstwa warzywnicze na tle wybranych krajów Unii Europejskiej, Naukowe Szkoły Głównej Gospodarstwa Wiejskiego w Warszawie Ekonomika i Organizacja Gospodarki Żywnościowej, 102, 67-86. 